\section{Ye. Tymchenko}

State Institution «Zaitsev V. T. Institute of General and Urgent Surgery of NAMSU», Kharkiv

(C) Tymchenko M. Ye.

\title{
STUDY OF ELECTROLYTE DISORDERS AS CRITERION-IMPORTANT MARKERS OF ENDOGENOUS INTOXICATION IN PATIENTS WITH ANASTOMOSIS LEAKEGE AGAINST A BACKGROUND OF RESECTION OF THE SMALL INTESTINE
}

Summary. The aim of the study was to study the dependence of ion exchange and saturation with iron transferrin on the background of increasing endotoxicosis, depending on the severity of the clinical course of acute small bowel obstruction and peritonitis.

Materials and methods. The research was carried out at the SI «ZIGUS NAMSU» and was based on the analysis of laboratory data of 63 patients with a failure of small intestinal anastomoses who in the future needed one of the options of resections of the segments of the small intestine, which were treated in the clinic from 2016 to 2019. All patients were divided into 3 groups according to the degree of physical severity of the condition on the APACHE II scale. The study was conducted in two stages: the first stage examined the content of zinc, copper and iron ions in the serum of all patients studied, the second stage of the study in patients evaluated the objective indicators of endogenous intoxication on the basis of leukocyte index of intoxication, index of content molecular weight, malonic aldehyde and diene conjugates in serum and iron levels in whole blood, as well as its serum.

Results and Discussion. The study of $\mathrm{Fe}^{2+}, \mathrm{Zn}^{2+}, \mathrm{Cu}^{2+}$ metabolism in the serum of all patients with inflammatory phenomena of the peritoneum on the background of anastomosis failure revealed significant changes. In the clinical group of patients with small bowel anastomosis, the level of zinc upon admission to the hospital was significantly increased. In the second stage, we conducted a study on the detection of an increase in serum iron content, endogenous intoxication and a decrease in transferrin iron saturation depending on the clinical course of the disease in patients with acute intestinal obstruction and peritonitis and the degree of contamination of the small intestine. The results shown in study indicate that in the studied patients, depending on the severity of the disease there is a progressive decrease in the content of iron in whole blood, along with an increase in its serum level against the background of a significant decrease in iron saturation and increase in objective indicators of endogenous intoxication.

Conclusions. On the basis of the results of the research, we can conclude that the increase of serum iron content with simultaneous decrease of transferrin iron saturation in the studied patients on the background of intensification of endotoxicosis depending on the severity of the condition, considering it as a factor of increasing the aggressiveness of bacterial resistance and flora correlates with the severity of the clinical course, according to which appropriate adequate additional corrective therapy is performed in complex surgery. treatment of patients with a small bowel anastomosis.

Key words: anastomotic leakage, endogenous intoxication, electrolyte disorders.

\section{Introduction}

One of the leading pathophysiological aspects in patients with inability of intestinal anastomo- ses is volemic and hemodynamic disorders due to the small intestine obstruction and peritonitis, regardless of the causes of emergence, leading role 
in the formation of a critical state of endogenous development. Endogenous intoxication and metabolic disorders in peritonitis are complex and multicomponent. The main source of endotoxicosis in inflammatory processes of the abdominal cavity is the intestine. Violation of the barrier function of the intestinal wall leads to endotoxemia, which in the absence of adequate treatment is progressive in nature [1-3].

Inability of the small intestine causes a delay in the passage of intestinal contents, an increase in the transformation of conditionally pathogenic microflora into pathogenic, which intensively multiplies, causing an increase in the processes of fermentation and decay with excess formation of highly toxic metabolic components, intestinal toxins. With the breakthrough of the barrier function of the intestine, the flow of toxins and $\mathrm{n}$-dentified toxic substances into the blood increases, which causes destabilization of cell membranes of tissues and organs, enhances the breakdown of proteins with the release of tissue toxins and biologically active amines, molecules, and molecules forming the general status of intensification of endotoxicosis. In the further development of pathological changes, the following factors are crucial: the gradual depletion of the detoxification potential of the liver, translocation of the intestinal microflora and its acquisition of pathogenic properties, the growth of the total mass of toxic products in internal environments, the development of systemic microcirculatory disorders, developmental disorders, progression of peritonitis (another source of intoxication) [2, 4-6].

Digestive disorders as well as progressive liver failure lead to inhibition of protein, fat and carbohydrate metabolism. The level of catabolic processes is increasing sharply, while the overall energy potential is reduced. Thus, in the pathogenesis of general disorders in the inflammation of the peritoneum, two processes occupy the main place: progressive endotoxicosis and metabolic disorders at all levels, which are closely interrelated and mutually enhance their action [7].

But at the same time, it should be noted that indicators of infectious complications of surgical interventions requiring resection of the segments of the small intestine have not tended to decrease in recent decades [8].

Changes in intracellular metabolism are known to be closely related to the physicochemical properties of membranes and are observed in diabetes, atherosclerosis, chemical intoxication, radiation exposure, emotional stress, tumor growth, and more. There is enough evidence that harmful factors of endogenous and exogenous origin are able to stimulate free radical reactions in the body, peroxidation of lipids, oxidative modification of proteins, nucleic acids [7-9].
Increasing the level of $\mathrm{Fe}^{2+}$ metal ions; $\mathrm{Zn}^{2+}$ and $\mathrm{Cu}^{2+}$ in the serum of patients with peritoneal inflammatory events may be due to disorders of functional organization, cytoplasmic membranes - cells, intracellular organelles, complex supramolecular catabolic and synthetic complexes, as well as reduced processes associated with the use of apatite ions. Taking into account the cofactor regulatory and energy functions of $\mathrm{Fe}^{2+}$ and $\mathrm{Cu}^{2+}$ ions, the increase of their content makes it possible to assume that there are disturbances of redox processes and many other metabolic processes. It is established that by increasing the ratio of oxidized coenzymes to reduced, it increases the oxidizing properties of the organism, activates the functioning of glycolysis, the cycle of three carboxylic acids, lithogenesis, and simultaneously inhibits the reactions of gluconeogenesis. The reduction of $\mathrm{Fe}^{3+}$ ferritin in hypoxia is carried out with the help of reduced substrates - NAD-N, NADP-H, glutathione and oxygen $[1,5,8,9]$.

The aim of the study was to study the dependence of ion exchange and saturation with iron transferrin on the background of increasing endotoxicosis, depending on the severity of the clinical course of acute small bowel obstruction and peritonitis.

\section{Materials and methods}

The research was carried out at the SI «ZIGUS NAMSU» and was based on the analysis of laboratory data of 63 patients with a failure of small intestinal anastomoses who in the future needed one of the options of resections of the segments of the small intestine, which were treated in the clinic from 2016 to 2019. All patients were divided into 3 groups according to the degree of physical severity of the condition on the APACHE II scale (Table 1).

Table 1

Distribution of patients on APACHE II scale

\begin{tabular}{|l|c|c|c|}
\hline \multicolumn{1}{|c|}{ Groups of patients } & Number & $\%$ & Mortality prognosis \\
\hline $\begin{array}{l}\text { Group } 1 \\
<10 \text { points } \\
(7,14 \pm 0,32, \text { от } 3 \text { до } 9)\end{array}$ & 22 & 34,9 & $<10$ \\
\hline $\begin{array}{l}\text { Group } 2 \\
\geq 10<20 \text { points } \\
(12,88 \pm 0,50, \text { от } 10 \text { до 19) }\end{array}$ & 27 & 42,9 & $10-22$ \\
\hline $\begin{array}{l}\text { Group 3 } \\
\geq 20 \text { points } \\
(25,62 \pm 1,3, \text { от } 21 \text { до } 37)\end{array}$ & 14 & 22,2 & $30-82$ \\
\hline
\end{tabular}

The control group consisted of 15 practically healthy subjects, who studied the content of electrolytes $\left(\mathrm{Fe}^{2+} ; \mathrm{Zn}^{2+} \mathrm{i} \mathrm{Cu}^{2+}\right)$ in the serum.

The study was conducted in two stages: the first stage examined the content of zinc, copper and iron ions in the serum of all patients studied, the second stage of the study in patients evaluated the objective indicators of endogenous intoxication on the basis of leukocyte index of intoxication, index 
of content molecular weight, malonic aldehyde and diene conjugates in serum and iron levels in whole blood, as well as its serum. Ion exchange was studied by means of an atomic absorption method on a Saturn-3 spectrophotometer.

Microbiological studies of the intestinal contents, which were administered during surgery, were performed according to standard guidelines [10, 11] (the species composition of the microflora was studied).

Statistical analysis was performed using Statistica 6.0 (StatSoft, Inc. 2001) and SPSS 7.5 on an Apple PC.

\section{Results}

The study of $\mathrm{Fe}^{2+}, \mathrm{Zn}^{2+}, \mathrm{Cu}^{2+}$ metabolism in the serum of all patients with inflammatory phenomena of the peritoneum on the background of anastomosis failure revealed significant changes (Table 2).

Table 2

Indicators of ion exchange in the serum of the studied patients $(\mathbf{M} \pm \mathbf{m})$

\begin{tabular}{|c|c|c|}
\hline \multirow{2}{*}{ Blood counts } & \multicolumn{2}{|c|}{ Observation groups } \\
\cline { 2 - 3 } & $\begin{array}{c}\text { Patients of the study groups } \\
(\mathrm{n}=63)\end{array}$ & $\begin{array}{c}\text { Control } \\
\text { group }(\mathrm{n}=15)\end{array}$ \\
\hline $\mathrm{Fe}^{2+}(\mathrm{mcmol} / \mathrm{l})$ & $40,12 \pm 3,11^{*}$ & $20,33 \pm 1,6$ \\
\hline $\mathrm{Zn}^{2+}(\mathrm{mcmol} / \mathrm{l})$ & $34,25 \pm 1,3^{*}$ & $23,2 \pm 1,21$ \\
\hline $\mathrm{Cu}^{2+}(\mathrm{mcmol} / \mathrm{l})$ & $22,31 \pm 1,14^{*}$ & $15,41 \pm 1,18$ \\
\hline
\end{tabular}

Note: * significant difference, $\mathrm{p}<0.05$.

The study of ion exchange of metals in the serum of patients with failure of the small intestinal anastomosis obtained in the first stage of the study revealed a significant $(p<0.05)$ increase in levels $\mathrm{Fe}^{2+}$ i $\mathrm{Cu}^{2+}$, this can be important diagnostic and prognostic value in justifying the severity of the disease.

In the clinical group of patients with small bowel anastomosis, the level of zinc upon admission to the hospital was significantly $(\mathrm{p}<0.05)$ increased $(31.12 \pm 1.2 \mathrm{mcmol} / \mathrm{l})$. It should be noted that on the 1st day after surgery in patients of the study group there was a tendency to further increase its concentration $(37.15 \pm 1.4 \mathrm{mcmol} / \mathrm{l})$, whereas by the time of discharge, the zinc content decreased to the lower limit of the reference values.

\section{Discussion}

It is known that a special place in the intensification of bacterial aggression, and at the same time in the growth of endotoxicosis in abdominal infection is a violation of homeostasis of metal-metal-enzyme systems. In the human body trace elements - metals play the role of basic modulators for the synthesis of specific organic structures and biologically active substances, maintaining the stability of homeostasis in a healthy body. In stressful situations, in particular in peritonitis, there are corresponding shifts in the redistribution of the content of trace elements of metals in tissues and organs so quickly that the body does not have time to adapt to changes in metabolic processes, contributing to the accumulation of biologically active products, nonspecific effects on normal clinical course of the pathological process.

It is known that trace elements - metals, such as biotics, are absolutely necessary specific factors for the growth, multiplication of bacteria and the formation of their virulence. It is also known that of all physiologically active metals-biotics, which can influence the restoration of the interaction of macro- and microorganisms, a particular role is played by the trace element iron. This is due to the fact that most bacteria are iron dependent because they require iron ions for their life cycle. In the blood plasma of free iron ions is a thousand times less than the amount necessary for their normal growth.

The presence in the healthy body of transferrin binding protein, which is normally saturated with iron by not more than $30 \%$, limits the bacteria supply of the required trace element and has a strong bacteriostatic effect.

In the second stage, we conducted a study on the detection of an increase in serum iron content, endogenous intoxication and a decrease in transferrin iron saturation depending on the clinical course of the disease in patients with inflammatory phenomena of the abdominal cavity against the background of anastomosis leakege and the degree of contamination of the small intestine.

Dynamics of endogenous intoxication, iron content in whole blood, serum iron and transferrin iron

Dynamics of endogenous intoxication, iron content in whole blood, serum and transferrin iron saturation depending on the severity of patients

\begin{tabular}{|l|c|c|c|c|c|c|c|c|}
\hline \multirow{2}{*}{$\begin{array}{c}\text { Groups of } \\
\text { patients }\end{array}$} & $\begin{array}{c}\text { Leukocyte } \\
\text { intoxication } \\
\text { index, units }\end{array}$ & $\begin{array}{c}\text { Index of } \\
\text { intoxication, } \\
\text { units }\end{array}$ & $\begin{array}{c}\text { Molecules } \\
\text { of medium } \\
\text { mass, units }\end{array}$ & $\begin{array}{c}\text { Malone } \\
\text { aldehyde, } \\
\text { nmol/mI }\end{array}$ & $\begin{array}{c}\text { Diene } \\
\text { conjugates, } \\
\text { units }\end{array}$ & \multicolumn{2}{|c|}{$\begin{array}{c}\text { Whole (momol/I) } \\
\text { blood }\end{array}$} & $\begin{array}{c}\text { Shorumsferrin, } \\
\text { Serum }\end{array}$ \\
\hline Norm $(n=15)$ & $0,70 \pm 0,067$ & $0,95 \pm 0,02$ & $0,27 \pm 0,01$ & $0,46 \pm 0,08$ & $1,42 \pm 0,04$ & $518,7 \pm 9,01$ & $203,3 \pm 1,6$ & $0,19 \pm 0,002$ \\
\hline $\begin{array}{l}\text { Group 1 } \\
(n=22)\end{array}$ & $4,18 \pm 0,12$ & $1,25 \pm 0,17$ & $0,54 \pm 0,01$ & $1,54 \pm 0,01$ & $2,64 \pm 0,07$ & $401,0 \pm 6,50$ & $21,64 \pm 2,02$ & $0,14 \pm 0,002$ \\
\hline $\begin{array}{l}\text { Group 2 } \\
(n=27)\end{array}$ & $5,54 \pm 0,08$ & $1,89 \pm 0,22$ & $0,62 \pm 0,01$ & $2,62 \pm 0,09$ & $3,02 \pm 0,08$ & $352,4 \pm 4,36$ & $31,76 \pm 4,02$ & $0,13 \pm 0,004$ \\
\hline $\begin{array}{l}\text { Group 3 } \\
(n=14)\end{array}$ & $6,10 \pm 0,38$ & $3,78 \pm 0,70$ & $0,74 \pm 0,03$ & $2,78 \pm 0,40$ & $3,56 \pm 0,16$ & $312,8 \pm 5,31$ & $51,82 \pm 0,03$ & $0,12 \pm 0,001$ \\
\hline
\end{tabular}

Note: significant difference from normal $(\mathrm{p}<0.05)$ 
saturation, depending on the severity of patients, which are given in table. 3 .

The results shown in table 3 indicate that in the studied patients, depending on the severity of the disease there is a progressive decrease in the content of iron in whole blood, along with an increase in its serum level against the background of a significant decrease in iron saturation and increase in objective indicators of endogenous intoxication .

Microbiological studies have shown that patients of 2 and 3 groups in the prestenotic department of the small intestine had significant changes in the bacterial flora, which was accompanied by an increase in the number of E.coli by $44 \%$; peptococci - by $68 \%$; clostridium - by $71.4 \%$; of bacterroids - by $14.2 \%$.

In view of the above, it can be assumed that the data revealed during the analysis of fluctuations in the level of zinc in patients with inflammatory phenomena of the peritoneum against the background of failure of the intestinal anastomosis indicate the stimulation of repair processes in response to the inflammatory process and subsequent surgery. Increasing its content on admission is certainly a response to stressful stress, which is due to the developing intestinal obstruction. In the future, surgery aimed at eliminating the peritonitis cell, in itself, leads to massive tissue damage and complication of repair processes. In this case, raising the level of zinc ions in the serum is a compensatory reaction that stimulates further reparative processes. $n$ addition, increasing zinc content in the serum activates the immune system, stimulates T-lymphocytes and mononuclear phagocytes, which we observed in the study.

The state of iron deficiency in whole blood is an important pathogenetic indicator of the clinical course of the pathological process, which causes a decrease in oxygen delivery to the cells, promotes inhibition of the synthesis of iron-binding proteins, in particular transferrin, and inhibition of the protective organism of the anastomosis. Given the value of iron as a bioelement, in maintaining the immune status in the body, it should be noted that its deficiency in the blood is a factor that leads to inhibition of antibody synthesis by lymphocytes and decrease the phagocytic function of leukocytes. At the same time, a significant impact on the amount and quality of humoral indicators of natural and acquired immunity: opsonins, precipitins, agglutinins, complement binding antibodies, antioxidants.

At the same time, the increase in serum iron content creates the conditions for increased absorption of microflora (as an absolutely necessary factor of their vital activity), which promotes the development of bacterial aggressiveness, as well as enhances the activity of free radical processes in the body as factors of intensification of endotoxicosis.

\section{Conclusions}

Thus, on the basis of the results of the research, we can conclude that the increase of serum iron content with simultaneous decrease of transferrin iron saturation in the studied patients on the background of intensification of endotoxicosis depending on the severity of the condition, considering it as a factor of increasing the aggressiveness of bacterial resistance and flora correlates with the severity of the clinical course, according to which appropriate adequate additional corrective therapy is performed in complex surgery. treatment of patients with a small bowel anastomosis.

\section{LITERATURE}

1. Fomin PD, Matviychuk OB. (2018). Tertiary peritonitis as a problem of abdominal surgery. Klinicheskaia Khirurgiia. 2018;1:49-51. https://doi.org/10.26779/2522 -я396.2018.01.49

2. Skripko VD, Kovalenko AL, Zaplutanov VA. Korrekcija narushenij mikrojelementnogo gomeostaza i okislitelnogo stressa u pacientov s ostroj tonkokishechnoj neprohodimostiu. Hirurgija. Zhurnal im. N.I. Pirogova. 2017;6: 5559. https://doi.org/10.17116/hirurgia2017655-59

3. Green J, Doughty L, Kaplan SS, Sasser H, Carcillo JA. The Tissue Factor and Plasminogen Activator Inhibitor Type-1 Response in Pediatric Sepsis-induced Multiple Organ Failure. Thromb Haemost. 2002;87(02): 218-23. https://doi.org/10.1055/s-0037-1612976

4. Orlov Y.I. Intravascular Hemolysis of Red Blood Cells in the Development of Organ Dysfunctions in Critical Conditions. General Reanimatology. 2008;4(2):88. (In Russ.) https://doi.org/10.15360/1813-9779-2008-2-88

5. Sartelli M, Abu-Zidan FM, Labricciosa FM, et al. Physiological parameters for Prognosis in Abdominal Sepsis (PIPAS) Study: a WSES observational study. World J
Emerg Surg. 2019;14:34. https://doi.org/10.1186/s13017019-0253-2

6. Karandin VI, Rozhkov AG, Tsarev MI, Nagayev RM, Tikhonov PA. Evaluation of the Severity of Surgical Endotoxicosis. General Reanimatology. 2009;5(5):49. (In Russ.) https://doi.org/10.15360/1813-9779-2009-5-49

7. Kryvoruchko IA, Boyko VV, Ivanova YV, Andreieshchev SA. Sepsis-3: renewed determinations, potential problems and further practical foot steps. Klinicheskaia Khirurgiia. 2019;86(6):60-72. https://doi.org/10.26779/25221396.2019.06.60

8. Berlot G, Tomasini A, Viviani M. SIRS, Sepsis, and MODS. Infection Control in the Intensive Care Unit:537-47. https://doi.org/10.1007/88-470-0361-X_24

9. Kim PK, Deutschman CS. Inflammatory responses and mediators. Surgical clinics. 2000;Vol.80;Iss.3:885-94. https://doi.org/10.1016/S0039-6109(05)70102-X

10. Predtechenskij VE. Rukovodstvo po klinicheskim laboratornym issledovanijam. Moskva.Medicina;1964:177p.

11. Voronina LN, Desenko VF, Kravchenko VN et al. Rukovodstvo k laboratornym i seminarskim zanjatijam po biologicheskoj himii. Har'kov. Osnova;1996:430p. 
ВИВЧЕННЯ

ЕЛЕКТРОЛІТНИХ

ПОРУШЕНЬ ЯК

КРИТЕРІАЛЬНО-

ВАЖЛИВИХ МАРКЕРІВ

ЕНДОГЕННӦ̈

ІНТОКСИКАЦІї

У ПАЦІЕНТІВ 3

НЕСПРОМОЖНІСТЮ

AНАCTOMOЗIB НА ФOHI

РЕЗЕКЦІї ТОНКОЇ КИШКИ

\section{М. С. Тимченко}

Резюме. Метою дослідження було вивчення залежності іонообміну та насичення трансферином заліза на фоні посилення ендотоксикозу залежно від тяжкості клінічного перебігу гострої непрохідності тонкої кишки та перитоніту.

Матеріали та методи. Дослідження проводилось у ДУ «ІЗНХ ім. В. Т. Зайцева НАМНУ» і базувалося на аналізі лабораторних даних 63 пацієнтів 3 недостатністю анастомозів тонкого кишечника, яким надалі потрібен один із варіантів резекції сегментів тонкої кишки, які лікувалися в клініці з 2016 по 2019 рік. Усі пацієнти були поділені на 3 групи за ступенем фізичної тяжкості стану за шкалою АРАСНЕ II. Дослідження проводилось у два етапи: на першому етапі досліджували вміст іонів цинку, міді та заліза в сироватці крові всіх досліджуваних пацієнтів, на другому етапі дослідження у пацієнтів оцінювали об’єктивні показники ендогенної інтоксикації на основі лейкоцитарного індексу інтоксикації, показник вмісту молекулярної маси, кон>югатів малонового альдегіду та дієну в сироватці крові та заліза в цільній крові, а також його сироватці. Результати і обговорення.

Результати та обговорення. Дослідження метаболізму $\mathrm{Fe}^{2+}$, $\mathrm{Zn}^{2+}, \mathrm{Cu}^{2+}$ у сироватці крові всіх пацієнтів із запальними явищами очеревини на тлі недостатності анастомозу виявило значні зміни. У клінічній групі пацієнтів з анастомозом тонкого кишечника рівень цинку при надходженні в лікарню значно підвищився. На другому етапі ми провели дослідження шодо виявлення збільшення вмісту заліза в сироватці крові, ендогенної інтоксикації та зниження насиченості трансферином залізом залежно від клінічного перебігу захворювання у пацієнтів з запальними явищами черевної порожнини на фоні неспроможності анастомозу та ступеня зараження тонкої кишки. Результати, показані в дослідженні, вказують на те, що у досліджуваних пацієнтів залежно від тяжкості захворювання спостерігається прогресуюче зниження вмісту заліза в цільній крові разом із підвищенням рівня його сироватки на тлі значного зниження рівня заліза насичення та підвищення об’єктивних показників ендогенної інтоксикації.

Висновки. На основі результатів дослідження можна зробити висновок, що збільшення вмісту заліза в сироватці крові з одночасним зниженням насиченості трансферином залізом у досліджуваних пацієнтів на фоні посилення ендотоксикозу залежно від тяжкості стану, розглядаючи його як Коефіцієнт підвищення агресивності бактеріальної резистентності та флори корелює 3 тяжкістю клінічного перебігу, згідно з яким в комплексній хірургії проводиться відповідна додаткова коригуюча терапія. лікування хворих з анастомозом тонкого кишечника.

Ключові слова: неспроможність анастомозу, ендогенна інтоксикація, електролітні розлади. 
ИЗУЧЕНИЕ

ЭЛЕКТРОЛИТНЫХ

НАРУШЕНИЙ КАК

КРИТЕРИАЛЬНО-ВАЖНЫХ

МАРКЕРОВ ЭНДОГЕННОЙ

ИНТОКСИКАЦИИ

У ПАЦИЕНТОВ С

НЕСОСТОЯТЕЛЬНОСТЬЮ

АНАСТОМОЗОВ НА ФОНЕ

РЕЗЕКЦИИ ТОНКОЙ

КИШКИ

\section{М. Е. Тимченко}

Резюме. Целью исследования было изучение зависимости ионообмена и насыщения трансферрином железа на фоне усиления эндотоксикоза в зависимости от тяжести клинического течения острой непроходимости тонкой кишки и перитонита.

Материалы и методы. Исследование проводилось в ГУ «ИОНХ им. В. Т. Зайцева НАМНУ» и базировалось на анализе лабораторных данных 63 пациентов с недостаточностью анастомозов тонкого кишечника, которым в дальнейшем нужен один из вариантов резекции сегментов тонкой кишки, которые лечились в клинике с 2016 по 2019 год. Все пациенты были разделены на 3 группы по степени физической тяжести состояния по шкале APACHЕ II. Исследование проводилось в два этапа: на первом этапе исследовали содержание ионов цинка, меди и железа в сыворотке крови всех исследуемых пациентов, на втором этапе исследования у пациентов оценивали объективные показатели эндогенной интоксикации на основе лейкоцитарного индекса интоксикации, показатель содержания молекулярной массы, кон'югатив малонового альдегида и диена в сыворотке крови и железа в цельной крови, а также его сыворотке.

Результаты и обсуждение. Исследования метаболизма $\mathrm{Fe}^{2+}$, $\mathrm{Zn}^{2+}, \mathrm{Cu}^{2+}$ в сыворотке крови всех пациентов с воспалительными явлениями брюшины на фоне недостаточности анастомоза выявило значительные изменения. В клинической группе пациентов с анастомозом тонкого кишечника уровень цинка при поступлении в больницу значительно повысился. На втором этапе мы провели исследования по выявлению увеличение содержания железа в сыворотке крови, эндогенной интоксикации и снижения насыщенности трансферрина в зависимости от клинического течения заболевания у пациентов с воспалительными явлениями брюшной полости на фоне несостоятельности анастомоза и степени заражения тонкой кишки. Результаты, показанные в исследовании, указывают на то, что в исследуемых пациентов в зависимости от тяжести заболевания наблюдается прогрессирующее снижение содержания железа в цельной крови вместе с повышением уровня его сыворотки на фоне значительного снижения уровня железа насыщения и повышение объективных показателей эндогенной интоксикации.

Bыводы. На основе результатов исследования можно сделать вывод, что увеличение содержания железа в сыворотке крови с одновременным снижением насыщенности трансферрина в исследуемых пациентов на фоне усиления эндотоксикоза в зависимости от тяжести состояния, рассматривая его как Коэффициент повышения агрессивности бактериальной резистентности и флоры коррелирует с тяжестью клинического течения, согласно которому в комплексной хирургии проводится соответствующая дополнительная корректирующая терапия. лечения больных с анастомозом тонкого кишечника.

Ключевые слова: несостоятельность анастомоза, эндогенная интоксикация, электролитные нарушения. 